\title{
Ehrlichiosis in Brazil
}

\author{
Erliquiose no Brasil \\ Rafael Felipe da Costa Vieira ${ }^{1}$; Alexander Welker Biondo ${ }^{2,3}$; Ana Marcia Sá Guimarães ${ }^{4}$; Andrea Pires dos Santos ${ }^{4}$; \\ Rodrigo Pires dos Santos ${ }^{5}$; Leonardo Hermes Dutra ${ }^{1}$; Pedro Paulo Vissotto de Paiva Diniz ${ }^{6}$; Helio Autran de Morais \\ Joanne Belle Messick'; Marcelo Bahia Labruna ${ }^{8}$; Odilon Vidotto ${ }^{1 *}$ \\ ${ }^{1}$ Departamento de Medicina Veterinária Preventiva, Universidade Estadual de Londrina - UEL \\ ${ }^{2}$ Departamento de Medicina Veterinária, Universidade Federal do Paraná - UFPR \\ ${ }^{3}$ Department of Veterinary Pathobiology, University of Illinois \\ ${ }^{4}$ Department of Veterinary Comparative Pathobiology, Purdue University, Lafayette \\ ${ }^{5}$ Seção de Doenças Infecciosas, Hospital de Clínicas de Porto Alegre, Universidade Federal do Rio Grande do Sul - UFRGS \\ ${ }^{6}$ College of Veterinary Medicine, Western University of Health Sciences \\ ${ }^{7}$ Department of Clinical Sciences, Oregon State University \\ ${ }^{8}$ Departamento de Medicina Veterinária Preventiva e Saúde Animal, Universidade de Sáo Paulo - USP
}

Received June 21, 2010

Accepted November 3, 2010

\begin{abstract}
Ehrlichiosis is a disease caused by rickettsial organisms belonging to the genus Ehrlichia. In Brazil, molecular and serological studies have evaluated the occurrence of Ehrlichia species in dogs, cats, wild animals and humans. Ehrlichia canis is the main species found in dogs in Brazil, although E. ewingii infection has been recently suspected in five dogs. Ehrlichia chaffeensis DNA has been detected and characterized in mash deer, whereas E. muris and E. ruminantium have not yet been identified in Brazil. Canine monocytic ehrlichiosis caused by E. canis appears to be highly endemic in several regions of Brazil, however prevalence data are not available for several regions. Ehrlichia canis DNA also has been detected and molecularly characterized in three domestic cats, and antibodies against $E$. canis were detected in free-ranging Neotropical felids. There is serological evidence suggesting the occurrence of human ehrlichiosis in Brazil but its etiologic agent has not yet been established. Improved molecular diagnostic resources for laboratory testing will allow better identification and characterization of ehrlichial organisms associated with human ehrlichiosis in Brazil.
\end{abstract}

Keywords: Ehrlichia sp., domestic animals, wild animals, humans.

\section{Resumo}

Erliquiose é uma doença causada por rickettsias pertencentes ao gênero Ehrlichia. No Brasil, estudos sorológicos e moleculares têm avaliado a ocorrência de espécies de Ehrlichia em cães, gatos, animais selvagens e seres humanos. Ehrlichia canis é a principal espécie em cães no Brasil, embora a infecção por E. ewingii tenha, recentemente, despertado suspeita em cinco cães. O DNA de E. chaffeensis foi detectado e caracterizado em cervo-do-pantanal, enquanto que E. muris e E. ruminantium ainda não foram identificadas no Brasil. A erliquiose monocítica canina causada pela $E$. canis parece ser altamente endêmica em muitas regióes do Brasil, embora dados de prevalência não estejam disponíveis em muitas delas. O DNA de E. canis também foi detectado e caracterizado em três gatos domésticos, enquanto anticorpos contra E. canis foram detectados em felídeos neotropicais de vida livre. Evidências sorológicas sugerem a ocorrência de erliquiose humana no Brasil, entretanto, o agente etiológico ainda não foi identificado. A melhoria do diagnóstico molecular promoverá a identificação e caracterização de espécies associadas à erliquiose humana no Brasil.

Palavras-chave: Ehrlichia sp., animais domésticos, animais silvestres, humanos.

\footnotetext{
${ }^{*}$ Corresponding author: Odilon Vidotto

Departamento de Medicina Veterinária Preventiva,

Universidade Estadual de Londrina - UEL, Pr 445, Km 380,

CEP 86051-990, Londrina - PR, Brazil;

e-mail: vidotto@uel.br
} 


\section{Introduction}

Ehrlichia are Gram-negative, pleomorphic, obligate intracellular bacteria that infect a wide range of mammals. The genus initially included 10 species classified based on the host cell infected: monocytes (E. canis, E. risticii, E. sennetsu), granulocytes (E. ewingii, E. equi, E. phagocytophila, human granulocytic ehrlichiosis [HGE] agent), and thrombocytes (E. platys). Based on sequences of $16 \mathrm{~S}$ ribosomal RNA (rRNA) and other genes (e.g., groESL operon and surface protein genes), the genus Ehrlichia was rearranged and currently consists of five species: E. canis, E. chaffeensis, E. ewingii, E. muris and E. ruminantium (formerly Cowdria ruminantium). The Ehrlichia genus belongs to the family Anaplasmataceae of the order Rickettsiales (DUMLER et al., 2001). The remaining organisms were reclassified into the Anaplasma genus: $A$. platys (formerly E. platys) and A. phagocytophilum (a combination of organisms previously known as E. equi, E. phagocytophila and HGE agent), and into the Neorickettsia genus: $N$. helminthoeca, $N$. risticii (formerly E. risticii) and $N$. sennetsu (formerly E. sennetsu). The organisms not currently belonging to the genus Ehrlichia will not be further discussed in this review.

The organism was first described in dogs by Donatien and Letosquard (1935) in Algeria. After a major epizootic during the Vietnam War ehrlichiosis was characterized as a dog disease due to the infection and death of many military working German Shepherd dogs (HUXSOLL et al., 1970). In Brazil, E. canis was first reported in dogs from the city of Belo Horizonte, State of Minas Gerais, Southeastern Brazil (COSTA et al., 1973).

Ehrlichia organisms are mainly transmitted through the bite of an infected tick. This explains the higher prevalence of ehrlichiosis in tropical and subtropical regions due to the geographical distribution of vectors (ANDEREG; PASSOS, 1999). Thus, the presence of known competent tick vectors as well as reservoir hosts largely determine where ehrlichiosis is found. For instance, E. canis infecting dogs is mainly transmitted by Rhipicephalus sanguineus (DANTAS-TORRES, 2008), E. ruminantium (cattle) by ticks of genus Amblyomma, E. chaffeensis (deer) and E. ewingii (human and dogs) by $A$. americanum and Dermacentor variabilis (DUMLER et al, 2001; YABSLEY, 2010), and E. muris (rodents) by Haemaphysalis flava and Ixodes persulcatus (INOKUMA et al., 2007). Other tick species, such as $A$. cajennense, have been suspected to act as vectors of $E$. canis in rural areas (COSTA JR et al., 2007).

Several methods with varying degrees of sensitivity and specificity can be used to detect Ehrlichia organisms. In the past, Ehrlichia species were identified using light microscopy by finding elementary bodies, initial bodies or morulae in the host cell cytoplasm of Romanowsky-stained blood smears (Figure 1) (HILDEBRANDT et al., 1973). Unfortunately, this technique lacks sensitivity and specificity. Indirect immunofluorescence assay (IFA) was the traditional test to diagnose human and canine monocytic ehrlichiosis (Figure 2) (RISTIC et al., 1972; WANER et al., 2001; AGUIAR et al., 2007a; DUMLER et al., 2007; SAITO et al., 2008). Although this technique is still widely used, a significant number of false positives may occur due to cross-reactivity with other organisms from the genera Ehrlichia, Anaplasma and Neorickettsia (RISTIC et al., 1981; HARRUS et al.,
2002; OLANO; WALKER, 2002; PADDOCK; CHILDS, 2003). Several other serological tests are now commercially available to diagnose ehrlichiosis (e.g., Enzyme Linked Immunosorbent Assay (ELISA), immunoblot, competitive Enzyme Linked Immunosorbent Assay (cELISA)) (OHASHI et al., 1998; WANER et al., 2000; ALLEMAN et al., 2001; LÓPEZ et al., 2007; ZHANG et al., 2008). Diagnostic accuracy has been greatly enhanced by the introduction of culture and molecular techniques. In Brazil, E. canis was first cultivated in 2002 using DH82 cells (TORRES et al., 2002) and a Brazilian strain was molecularly characterized in 2008 using $d s b, 16 S$ rRNA and $p 28$ genes (AGUIAR et al., 2008). These organisms can all be grown in cell culture with exception of E. ewingii. However, this is a time-consuming technique not available in many laboratories. Cultures also require specialized laboratory facilities and highly trained personnel. Molecular detection of the Ehrlichia genus by polymerase chain reaction (PCR), nested-PCR and real-time PCR has been used to identify individuals infected either experimentally or naturally in both acute and chronic phase (MACIEIRA et al., 2005; DINIZ et al., 2007; LABRUNA et al., 2007; DAGNONE et al., 2009; FARIA et al., 2010; NAKAGHI et al., 2010). PCR is a more sensitive and specific test compared to other methods (IQBAL et al., 1994; PEIXOTO et al., 2005; LABRUNA et al., 2007), although falsepositive results can still occur (APFALTER et al., 2005).

The geographic distribution of some Ehrlichia species has not yet been fully established, although $E$. canis and E. chaffeensis have been described in most regions of the world (INOKUMA et al., 1999; COCCO et al., 2003; FABURAY et al., 2005; MASTRANDREA et al., 2006; PEREZ et al., 2006; TAMAMOTO et al., 2007; MORO et al., 2009, NDIP et al., 2009). Ehrlichiosis is widely detected across Brazil (Figure 3). Three species have been described to date in Brazil: E. canis (AGUIAR et al., 2007a; LABRUNA et al., 2007; UENO et al., 2009; DINIZ et al., 2007; OLIVEIRA et al., 2009a), E. ewingii (OLIVEIRA et al., 2009c) and E. chaffeensis (MACHADO et al., 2006). This is a review of recent studies on the occurrence of Ehrlichia species in domestic and wild animals, ticks and humans in Brazil.

\section{Companion Animals}

\section{Clinical findings of Ehrlichia canis infection in dogs}

Canine monocytic ehrlichiosis (CME) is a disease caused by $E$. canis and classically consists of three stages: acute, subclinical and chronic (NEER, 1998). The acute stage lasts two to four weeks and has non-specific clinical signs that may include apathy, anorexia, vomiting, fever, ocular and nasal discharge, weight loss, ocular lesions, lymphadenopathy, hepatosplenomegaly, and dyspnea (MOREIRA et al., 2003, 2005; CASTRO et al., 2004; AGUIAR et al., 2007b; ORIÁ et al., 2008; BORIN et al., 2009). Hematological findings in this phase may include normocytic normochromic anemia (MOREIRA et al., 2003, 2005; CASTRO et al., 2004; BORIN et al., 2009), leukopenia with a shift to the left (MOREIRA et al., 2003; BORIN et al., 2009) and thrombocytopenia (MOREIRA et al., 2003, 2005; 


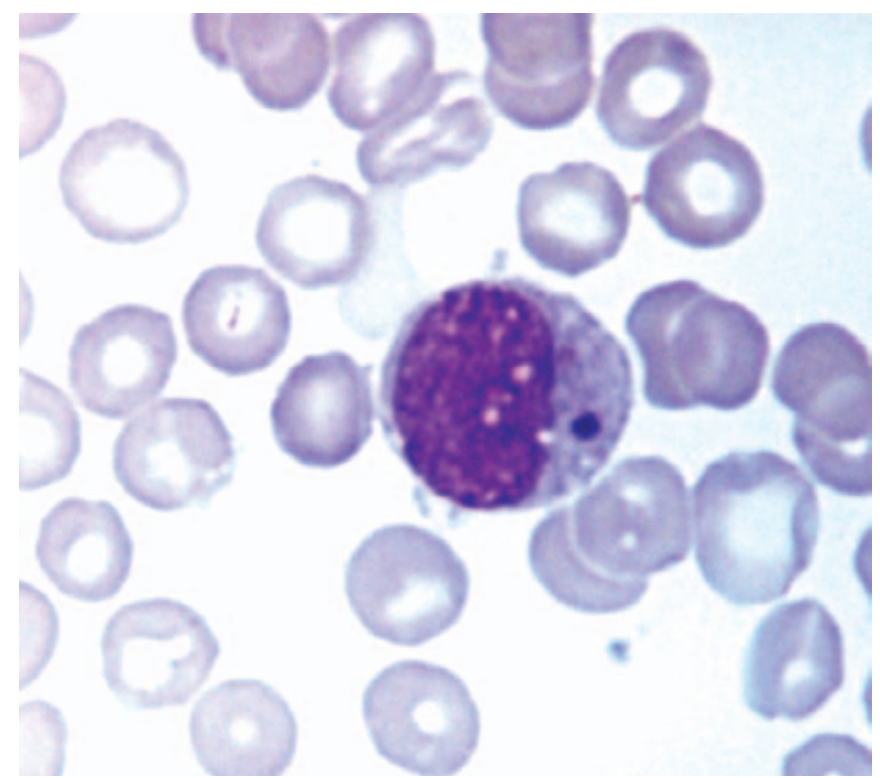

Figure 1. Light micrograph of Ehrlichia canis, Jaboticabal strain, inside a macrophage from an experimentally infected dog. Wright's-Giemsa (100x). Photograph kindly provided by Profa. Dra. Machado, R. Z.

CASTRO et al., 2004; BORIN et al., 2009; XAVIER et al., 2009). Cardiomyocyte injury has been identified in Brazilian dogs naturally infected with $E$. canis. In this population, dogs with acute ehrlichiosis were at a higher risk of developing myocardial cell injury than other sick dogs (DINIZ et al., 2008).

The subclinical phase usually starts 6 to 9 weeks post-infection. Laboratory findings during the subclinical stage include nonregenerative anemia (MOREIRA et al., 2003, 2005; ORIÁ et al., 2008; BORIN et al., 2009), leukopenia and thrombocytopenia (DAGNONE et al., 2003; BULLA et al., 2004; MOREIRA et al., 2005; ORIÁ et al., 2008; SANTOS et al., 2009; XAVIER et al., 2009). Altered platelet function is likely since dogs may present superficial bleeding such as epistaxis and petechia, even when platelet counts and coagulation profiles are within reference ranges (FRANK; BREITSCHWERDT, 1999; MOREIRA et al., 2005). In chronic cases, infected dogs fail to mount an effective immune response. Bone marrow involvement leads to pancytopenia (WALKER et al., 1970; MOREIRA et al., 2005) and death may occur due to hemorrhage secondary to thrombocytopathy (DAGNONE et al., 2001) or infections in neutropenic patients (HUXSOLL et al., 1970). It appears that CME occurs at any time throughout the year in many parts of Brazil. Tropical weather favors the proliferation of its main biological vector $R$. sanguineus (DANTAS-TORRES, 2008).

\section{Prevalence of Ehrlichia canis infection in dogs}

Ehrlichia canis was first reported in Brazil in 1973 (COSTA et al., 1973). Although the disease is currently described nationwide, prevalence data is only available for some regions (Table 1). The studies differ with respect to population, geographic area, presence of vector, and diagnostic test used. Therefore, comparison of

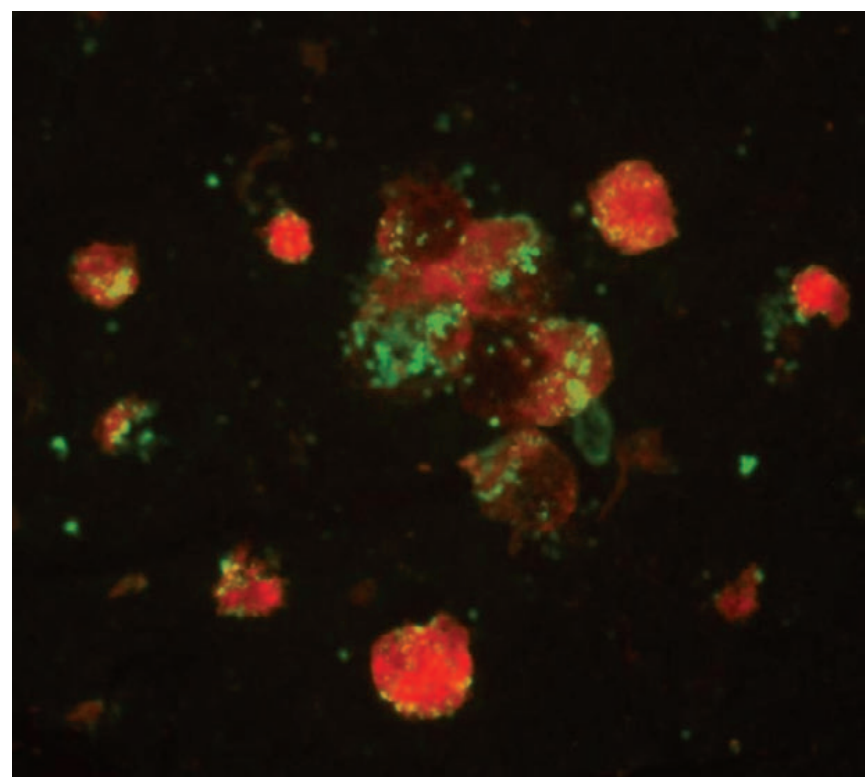

Figure 2. Indirect immunofluorescence assay (IFA) of Ehrlichia canis in serum from an infected $\operatorname{dog}(400 \times)$. Photograph kindly provided by Prof. Dr. Labruna, M. B.

epidemiological data among studies is difficult or not feasible. IFA and other serological methods may yield false-positive results because these techniques do not differentiate between infection and previous exposure to the organism, whereas false-negatives by PCR in peripheral blood also may occur in subclinically or chronically infected dogs. In the chronic phase, the pathological agent is present inside macrophages in the spleen (HARRUS et al., 1998) and not in peripheral blood (HARRUS et al., 2004), explaining the negative PCR results. The detection range by PCR varies among laboratories (MAANEN et al., 2004).

In Jaboticabal city, São Paulo State, Southeastern Brazil, 30 dogs with clinical signs suggestive of ehrlichiosis were tested by different diagnostic methods; $53 \%$ were positive by nestedPCR from the $16 \mathrm{~S}$ rRNA gene and $73 \%$ by serology $(63 \%$ by IFA and $70 \%$ by dot-ELISA). In this study, only $27 \%$ of the dogs were tested positive by all three methods (NAKAGHI et al., 2008). The prevalence of $E$. canis infection in dogs from different areas and from selected hospital populations from Southeastern Brazil ranged from 15\% (MACIEIRA et al., 2005) to $44.7 \%$ (COSTA JR et al., 2007). Table 1 summarizes the occurrence of E. canis in dogs from different geographic locations according to the type of population studied, total number of dogs evaluated in each study, and method of diagnosis. When dogs suspected to be infected based on suggestive clinical signs, such as pale mucous membranes, inappetence, apathy, vomiting, fever, lymphadenopathy, splenomegaly, epistaxis and others or laboratory data (anemia, thrombocytopenia) were tested, the prevalence increased from 40\% (UENO et al., 2009) to $92.3 \%$ (OLIVEIRA et al., 2000). The prevalence of $E$. canis infection in dogs from rural and urban areas of the State of Rio Grande do Sul without abnormal clinical or laboratory findings was 4.8\% (SAITO et al., 2008).

Using dot-ELISA an E. canis prevalence of $36 \%$ was found in a hospital population in the Ilhéus-Itabuna microregion, Bahia State, 


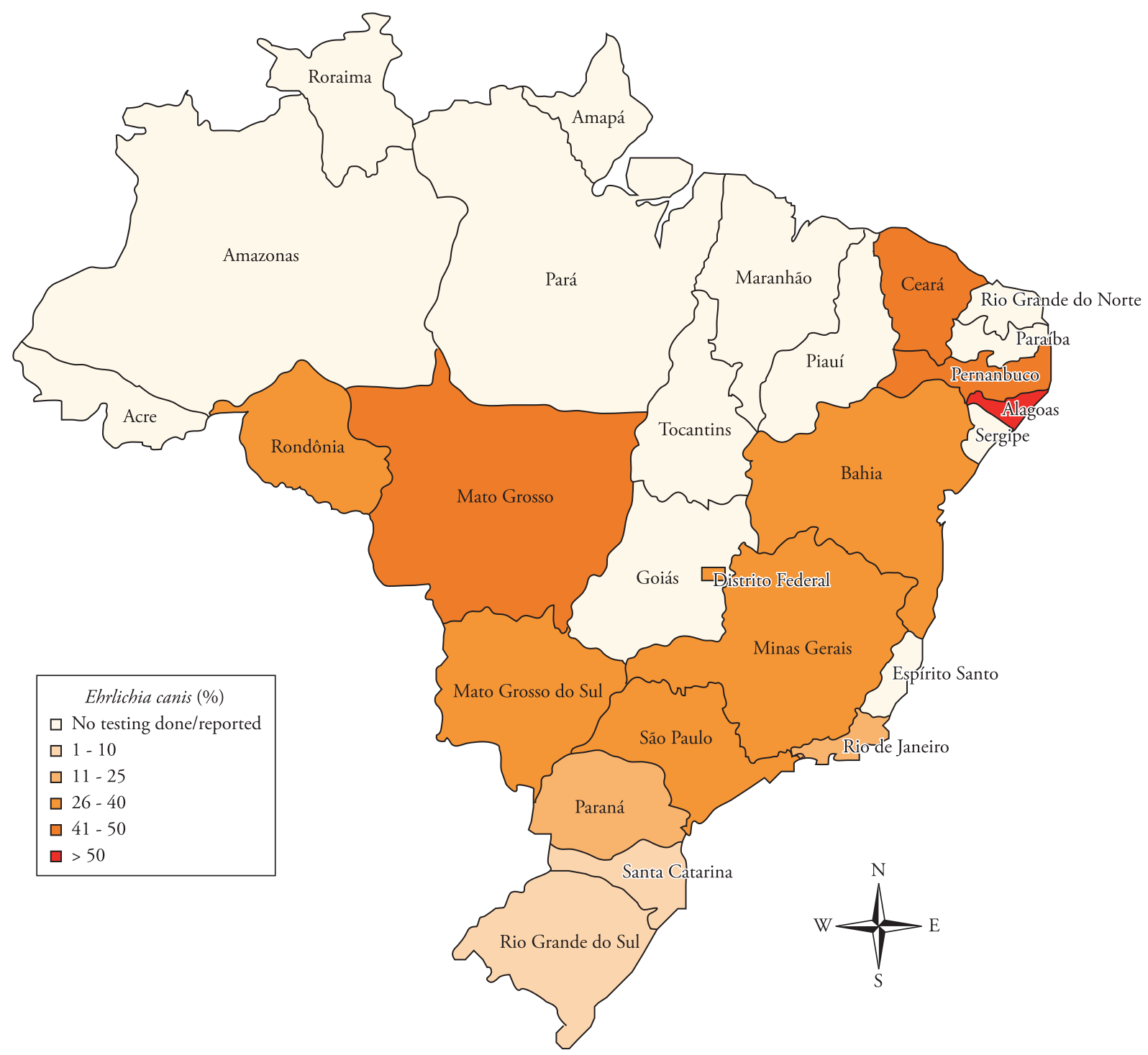

Figure 3. Geographical illustration of serologic and molecular occurrence of Ehrlichia spp. infections in dogs from Brazil based on data from Table 1. Geographic Information System, ARCGIS 9, Version 9.2, ERSI.

Northeastern Brazil (CARLOS et al., 2007). Using nested-PCR, only $7.8 \%$ of dogs from a hospital population had E. canis DNA in their blood in this same microregion (CARVALHO et al., 2008). It is important to notice that since these studies were conducted in a hospital population, prevalence data may not reflect the actual situation of canine ehrlichiosis in that region. A national seroprevalence of $E$. canis and other agents was performed in 2,553 dogs presented to 138 veterinary practices in 12 Brazilian States using dot-ELISA as the diagnostic method. Dogs were presented to the clinic for routine vaccinations, examinations, or other procedures (LABARTHE et al., 2003). The geographical distribution of Ehrlichia spp. infections in dogs from Brazil by serologic and molecular methods is illustrated in Figure 1.

In a survey of dogs from rural and urban areas by IFA, the prevalence found in Mato Grosso State (42.5\%), Central-West Brazil (SILVA et al., 2010), was higher than in Rondônia State (36\%), Northern Brazil (AGUIAR et al., 2007b), Bahia State (35.6\%),
Northeastern Brazil (SOUZA et al., 2010), and Rio Grande do Sul State (4.8\%), Southern Brazil (SAITO et al., 2008). The reasons for different prevalences in Southern, Central-West and NorthernNortheastern Brazil are unknown, since $R$. sanguineus is abundant throughout these urban and rural areas of Brazil (LABRUNA; PEREIRA, 2001; DANTAS-TORRES et al., 2006). However, $R$. sanguineus ticks can adopt different strategies to seek their hosts and these strategies may vary widely from region to region (DANTAS-TORRES, 2008). As previously described, climatic (KEEFE et al., 1982), or habitat conditions where the animals live (SAINZ et al., 1996) may account for the differences found.

\section{Risk factors of Ehrlichia canis infection in dogs}

In a study at the Veterinary Teaching Hospital (VTH), Universidade Estadual de Londrina, Paraná State, Southern Brazil, a random representative sample of the canine population at that 
Table 1. Occurrence of ehrlichial infection in dogs from Brazil.

\begin{tabular}{|c|c|c|c|c|c|}
\hline Geographical area & Population & N. dogs & Diagnostic method & Occurrence & Reference \\
\hline \multicolumn{6}{|l|}{ Southeastern Brazil } \\
\hline \multirow[t]{2}{*}{ Jaboticabal, SP } & Suspect & 52 & dot-ELISA ${ }^{1}$ & $48 / 52(92.3 \%)$ & Oliveira et al. (2000) \\
\hline & Positive by dot-ELISA & 48 & Blood smear examination & $1 / 48(2 \%)$ & \\
\hline \multirow[t]{2}{*}{ Jaboticabal, SP } & Suspect & 51 & IFA & $34 / 51(66.6 \%)$ & Oriá et al. (2008) \\
\hline & & & dot-ELISA ${ }^{1}$ & $44 / 51(86.2 \%)$ & \\
\hline Jaboticabal, SP & Suspect & 25 & $\begin{array}{l}\text { Nested PCR for } \\
16 S \text { rRNA gene }\end{array}$ & $22 / 25(88 \%)$ & Dagnone et al. (2009) \\
\hline \multirow{2}{*}{ Jaboticabal, SP } & & & dot-ELISA ${ }^{1}$ & $21 / 30(70 \%)$ & \\
\hline & & & $\begin{array}{l}\text { Nested PCR for } \\
16 S \text { rRNA gene }\end{array}$ & $16 / 30(53.3 \%)$ & \\
\hline Jaboticabal, SP & Suspect & 40 & $\begin{array}{l}\text { Nested PCR for } \\
\text { 16S rRNA gene }\end{array}$ & $29 / 40(72.5 \%)$ & Faria et al. (2010) \\
\hline Botucatu, SP & & & IFA & $145 / 198(73.2 \%)$ & Diniz et al. (2007) \\
\hline \multirow[t]{2}{*}{ Botucatu, SP } & Suspect & 70 & PCR for dsb gene & $28 / 70(40 \%)$ & Ueno et al. (2009) \\
\hline & & & Blood smear examination & $10 / 70(7 \%)$ & \\
\hline \multirow[t]{3}{*}{ Botucatu, SP } & Hospital & 217 & $\begin{array}{l}\text { Nested PCR for } \\
16 S \text { rRNA gene }\end{array}$ & 67/217 (30.9\%) & Bulla et al. (2004) \\
\hline & non-thrombocytopenic & 71 & & $1 / 71(1.4 \%)$ & \\
\hline & thrombocytopenic & 146 & & $66 / 146(45 \%)$ & \\
\hline São Paulo State & Random & 671 & dot-ELISA ${ }^{2}$ & $104 / 671(15.5 \%)$ & Labarthe et al. (2003) \\
\hline Rio de Janeiro State & Random & 422 & dot-ELISA ${ }^{2}$ & $125 / 422(29.6 \%)$ & Labarthe et al. (2003) \\
\hline Minas Gerais State & Random & 446 & dot-ELISA ${ }^{2}$ & $93 / 446(20.9 \%)$ & Labarthe et al. (2003) \\
\hline Rio de Janeiro, RJ & Random & 226 & PCR for $16 S$ rRNA gene & $34 / 226(15 \%)$ & Macieira et al. (2005) \\
\hline Minas Gerais State & Rural area & 226 & IFA & $101 / 226(44.7 \%)$ & Costa Jr et al. (2007) \\
\hline Minas Gerais State & Urban area & 101 & Blood smear examination & $16 / 101(16 \%)$ & Soares et al. (2006) \\
\hline Minas Gerais State & Hospital & 4407 & Blood smear examination & $251 / 4407(5.7 \%)$ & Borin et al. (2009) \\
\hline \multicolumn{6}{|l|}{ Southern Brazil } \\
\hline Rio Grande do Sul State & Random & 389 & IFA & $19 / 389(4.8 \%)$ & Saito et al. (2008) \\
\hline Rio Grande do Sul State & Random & 356 & dot-ELISA ${ }^{2}$ & $6 / 356(1.7 \%)$ & Labarthe et al. (2003) \\
\hline Paraná State & Random & 43 & dot-ELISA ${ }^{2}$ & $2 / 43(4.7 \%)$ & Labarthe et al. (2003) \\
\hline Londrina, PR & Random & 381 & $\operatorname{dot}-E_{L I S A}^{2}$ & $87 / 381(22.8 \%)$ & Trapp et al. (2006) \\
\hline Londrina, PR & $\begin{array}{l}\text { Anemic and/or thrombo- } \\
\text { cytopenic }\end{array}$ & 129 & PCR for $16 \mathrm{~S}$ rRNA gene & $28 / 129(22 \%)$ & Dagnone et al. (2003) \\
\hline Santa Catarina State & Random & 142 & dot-ELISA ${ }^{2}$ & $1 / 142(0.7 \%)$ & Labarthe et al. (2003) \\
\hline \multicolumn{6}{|l|}{ Northern Brazil } \\
\hline \multirow[t]{3}{*}{ Montenegro, RO } & Random & 314 & IFA & $97 / 314(31 \%)$ & Aguiar et al. (2007b) \\
\hline & Urban area & 153 & & $58 / 153(38 \%)$ & \\
\hline & Rural area & 161 & & $40 / 161(25 \%)$ & \\
\hline \multicolumn{6}{|l|}{ Northeastern Brazil } \\
\hline Salvador, BA & Random & 472 & IFA & $168 / 472(35.6 \%)$ & Souza et al. (2010) \\
\hline Ilhéus-Itabuna, BA & Hospital & 200 & dot-ELISA & $72 / 200(36 \%)$ & Carlos et al. (2007) \\
\hline Ilhéus-Itabuna, BA & Hospital & 153 & $\begin{array}{l}\text { Nested PCR for } \\
\text { 16S rRNA gene }\end{array}$ & $12 / 153(7.8 \%)$ & Carvalho et al. (2008) \\
\hline Bahia State & Random & 117 & dot-ELISA ${ }^{2}$ & $42 / 117(35.9 \%)$ & Labarthe et al. (2003) \\
\hline
\end{tabular}

${ }^{1}$ Immunocomb, Biogal; ${ }^{2} \mathrm{SNAP}^{\circ}$ 3DX, Idexx. 
Table 1. Continued...

\begin{tabular}{|c|c|c|c|c|c|}
\hline Geographical area & Population & N. dogs & Diagnostic method & Occurrence & Reference \\
\hline Ceará State & Random & 11 & dot-ELISA ${ }^{2}$ & $5 / 11(45.5 \%)$ & Labarthe et al. (2003) \\
\hline Pernambuco State & Random & 105 & dot-ELISA ${ }^{2}$ & $52 / 105(49.5 \%)$ & Labarthe et al. (2003) \\
\hline Alagoas State & Random & 11 & dot-ELISA ${ }^{2}$ & $6 / 11(54.5 \%)$ & Labarthe et al. (2003) \\
\hline \multicolumn{6}{|l|}{ Central-West Brazil } \\
\hline Cuiabá, MT & Random & 254 & IFA & $108 / 254(42.5 \%)$ & Silva et al. (2010) \\
\hline Campo Grande, MS & Suspect & 26 & $\begin{array}{l}\text { Nested PCR for } \\
16 S \text { rRNA gene }\end{array}$ & $10 / 26(38.4 \%)$ & Dagnone et al. (2009) \\
\hline Mato Grosso do Sul State & Random & 126 & dot-ELISA ${ }^{2}$ & $45 / 126(35.7 \%)$ & Labarthe et al. (2003) \\
\hline Federal District & Random & 101 & dot-ELISA ${ }^{2}$ & $24 / 101(23.8 \%)$ & Labarthe et al. (2003) \\
\hline
\end{tabular}

${ }^{1}$ Immunocomb, Biogal; ${ }^{2} \mathrm{SNAP}^{\oplus}$ 3DX, Idexx.

institution was tested. Eighty-seven out of 381 (22.8\%) dogs were seropositive for ehrlichiosis using a commercially available immunoenzymatic dot-ELISA (SNAP 3DX, IDEXX Laboratories Inc., Portland, ME, USA) assay. The groups at higher risk of being seropositive to ehrlichiosis than the general population included: dogs older than 1 year, previously exposed to ticks and presence of neurological signs. Dogs seropositive for B. vogeli were more likely to be seropositive to E. canis and 54/381 (14.2\%) of these dogs had antibodies against both agents (TRAPP et al., 2006). In another study using thrombocytopenia and anemia as screeners for $E$. canis infection, $22 \%$ of 129 dogs tested positive for $E$. canis DNA by PCR at the same VTH (DAGNONE et al., 2003).

Most veterinary clinicians in Brazil use the presence of clinical and/or laboratorial findings to make a presumptive diagnosis of $E$. canis infection in dogs. At the Botucatu VTH, Southeastern Brazil, 217 canine blood samples randomly obtained from routine tests made at the Clinical Pathology Laboratory were divided into two groups based on platelet count: 71 nonthrombocytopenic and 146 thrombocytopenic. This population has an unexpectedly high prevalence of thrombocytopenia but unfortunately the randomization method was not described in the study. Thrombocytopenic dogs were divided into those with mild thrombocytopenia (62/146 dogs, platelets count between $100,000-200,000 / \mu \mathrm{L})$ and severe thrombocytopenia (84/146 dogs, less than $100,000 / \mu \mathrm{L})$. Sixty-seven $(31 \%)$ of all dog blood samples in the study were positive using a nested-PCR protocol, whereas $45 \%$ of thrombocytopenic dogs were positive. Twentyone percent of the dogs with mild and $63 \%$ of dogs with severe thrombocytopenia had ehrlichial DNA amplified by nested-PCR from the 16S rRNA gene. In this study the authors suggested that in endemic areas dogs with severe thrombocytopenia are more likely to be infected by $E$. canis infection (BULLA et al., 2004). In Rio de Janeiro, Southeastern Brazil, 226 dogs presented at private clinics were sampled and divided into thrombocytopenic (112/226) and non-thrombocytopenic (114/226). Ehrlichia canis infection was documented in $30(27 \%)$ dogs with thrombocytopenia, but only in 4 (3\%) non-thrombocytopenic animals using a PCR assay specific for the $16 \mathrm{~S}$ rRNA gene. Anemia was found in $60 \%$ of thrombocytopenic dogs that were PCR-positive (MACIEIRA et al., 2005). In Ribeirão Preto, Southeastern Brazil, 86/221 dogs (39\%) from private veterinary university hospitals were positive for $E$. canis by nested-PCR for the $16 \mathrm{~S}$ rRNA gene, 57/107 (53\%) were thrombocytopenic and 29/114 (25\%) were non-thrombocytopenic (SANTOS et al., 2009).
In the city of Jaboticabal, Southeastern Brazil, 51 dogs with uveitis tested positive to E. canis infection by IFA (66.6\%) and dot-ELISA (86.2\%). Anemia and thrombocytopenia were the most common hematological abnormalities found. A high association between clinical uveitis and positive serology for E. canis was demonstrated in this study (ORIÁ et al., 2008). In another study in the city of Jaboticabal, 52 dogs suspected of naturally acquired ehrlichiosis were selected at the VTH and tested by a commercial ELISA. A high prevalence of seropositive dogs $(92.3 \%)$ was found. The most common clinical and laboratorial findings were inappetence, apathy, anemia and thrombocytopenia (OLIVEIRA et al., 2000).

Seroprevalence by IFA was determined in three rural areas of Minas Gerais State, Southeastern Brazil using 226 dogs living in these areas. Ehrlichia canis prevalence in this study ranged from 24.7-65.6\% (COSTA JR et al., 2007). In this study, male dogs $>2$ years of age and those infested by ticks were at high risk of being seropositive to $E$. canis (COSTA JR et al., 2007). In a survey conducted in urban areas of Minas Gerais State, blood samples were collected from 51 dogs that were restricted to house backyards and 50 dogs that lived in apartments. E. canis was found by blood smear examination in $16 \%$ of dogs from houses with grassy yards, but in none of the dogs restricted to apartments. $R$. sanguineus was the only tick found in this study (SOARES et al., 2006). Differences on $E$. canis prevalence between these two studies may be due to different detection methods.

Rhipicephalus sanguineus can also transmit other hemoparasites (DANTAS-TORRES, 2008) and since it is widespread in Brazil (LABRUNA; PEREIRA, 2001), it is relatively common to find $E$. canis-infected dogs co-infected with Anaplasma sp. (MOREIRA et al., 2003; DAGNONE et al., 2003, 2009), Babesia sp. (MOREIRA et al., 2003; SOARES et al., 2006; TRAPP et al., 2006; BORIN et al., 2009), Bartonella sp. (DINIZ et al., 2007), Hepatozoon sp. (O'DWYER et al., 2006; MUNDIM et al., 2008), Leishmania sp. (DINIZ et al., 2007) and Mycoplasma sp. (MOREIRA et al., 2003, 2005).

Blood smear examination is not an effective diagnostic method as morulae are visualized only during the acute phase and the percentage of infected cells is usually less than 1\% (CADMAN et al., 1994). Diagnostic sensitivity between cytological methods was assessed in 50 dogs naturally infected by E. canis. During the acute phase of the disease, the highest sensitivities were found in buffy coats $(66 \%)$ and lymph nodes $(60.4 \%)$ compared to peripheral 
blood (8\%) examinations (MYLONAKIS et al., 2003). Using 35 samples collected from dogs suspected of being infected with E. canis, based on clinical signs and presence of thrombocytopenia, 17 dogs (48.6\%) showed intracytoplasmatic morulae in spleen aspiration and only two (5.7\%) showed in buffy coat, however E. canis DNA was isolated in 29/40 (72.5\%) spleen samples and 30/40 (75\%) whole blood samples (FARIA et al., 2010). Moreover, 51 blood samples from dogs with both clinical signs consistent with ehrlichiosis and the presence of intracytoplasmatic inclusion bodies or morulae-like forms in white blood cells were submitted to molecular analysis. Thirty-two (64\%) dog samples were positive for $E$. canis by nested-PCR for the $16 \mathrm{~S}$ rRNA gene (DAGNONE et al., 2009). Thus, an absence of parasites in blood smears does not rule out the possibility of infection (HOSKINS, 1991).

\section{Ehrlichia ewingii infection in dogs}

In Minas Gerais State, Southeastern Brazil, 5/100 (5\%) dogs tested positive by nested-PCR for the 16S rRNA gene of E. ewingii. These same dogs were also positive by a second PCR assay targeting a fragment of the ehrlichial $d s b$ gene. Four animals had anemia and one of them also had thrombocytopenia. This was the first study to provide evidence of canine infection caused by E. ewingii in Brazil (OLIVEIRA et al., 2009c), however species confirmation by DNA sequencing was not reported. Given that a previous study documented false-positive amplifications, especially when targeting the 16S rRNA by PCR (SUKSAWAT et al., 2001), other genes should be analyzed to confirm $E$. ewingii infection and thus the initial results from Oliveira et al. (2009c) remain to be confirmed.

\section{Ehrlichiosis in Cats}

Antibodies against E. canis antigens have been described in domestic cats in a few countries (MATTHEWMAN et al., 1996; PEAVY et al., 1997; ORTUÑO et al., 2005; SOLANOGALLEGO et al., 2006) and documented clinical cases of ehrlichiosis in these animals are rare (BREITSCHWERDT et al., 2002). Ehrlichia organisms have not been cultured from feline samples; evidence of infection came exclusively from serological and molecular studies (BREITSCHWERDT et al., 2002; OLIVEIRA et al., 2009b). Nevertheless, Ehrlichia canis-like organisms were detected by PCR and DNA sequencing in cats from Brazil and North America (BREITSCHWERDT et al., 2002; OLIVEIRA et al., 2009b). The first molecular detection of $E$. canis in Brazilian cats was reported in a study at a VTH of Minas Gerais State, Southeastern Brazil, in which blood samples from $3 / 15$ cats tested positive by nested-PCR for the $16 \mathrm{~S}$ rRNA gene. The $E$. canis sequence, a fragment of the $16 \mathrm{~S}$ rRNA gene, showed $100 \%$ identity with the $E$. canis sequence obtained from dogs from the same study area (OLIVEIRA et al., 2009a, 2009b). Further studies are needed to better characterize the Ehrlichia spp. involving other genes, transmission, pathogenesis and clinical presentation in cats.

\section{Wildlife Animals}

Cervid species may be infected with Ehrlichia organisms (YABSLEY et al., 2002; MACHADO et al., 2006; KAWAHARA et al., 2009; LEE et al., 2009). In the United States, white-tailed deer (Odocoileus virginianus) is considered the main reservoir of E. chaffensis and possibly of E. ewingii (YABSLEY et al., 2002; KAWAHARA et al., 2009). The first molecular detection of $E$. chaffeensis in Brazil was reported on the border of São Paulo and Mato Grosso do Sul States, between Southeastern and Central-Western regions of Brazil. In this study, 3/7 captured marsh deers (Blastocerus dichotomus) tested positive by nested-PCR for $E$. chaffeensis infection (MACHADO et al., 2006). Sequence analysis from positive samples showed $97 \%$ identity with sequences deposited in GenBank. Two out of three positive $E$. chaffeensis-positive marsh deer samples were also positive for Anaplasma marginale by nested-PCR.

Ehrlichia ruminantium infection in ruminants has been reported only in Africa and Caribbean region. Some non-African cervids are also known to be susceptible to this agent, including the whitetailed deer, the Timor deer (Cervus timorensis) and chital (Axis axis) (PETER et al., 2002). Recently, an Ehrlichia sp. closely related to E. ruminatium was detected in white-tailed deer from the United States, suggesting that the range of Ehrlichia species infecting these animals is broader than first thought (YABSLEY et al., 2008). To date, there are no reports of other Ehrlichia species rather than E. chaffeensis in wild ruminants from Brazil; monitoring of these animals is highly desired.

An E. canis serological survey by IFA of 20 free-ranging felids (18 pumas [Puma concolor], one ocelot [Leopardus pardalis] and two spotted cats [Leopardus tigrinus]) from different parts of Brazil was conducted and antibodies against $E$. canis were detected only in one puma (FILONI et al., 2006). Since IFA has high cross-reactivity with members of Anaplasmataceae family, definitive diagnosis of E. canis infection cannot be ensured. In another study, 72 blood samples from wild captive felids ( 9 pumas [P. concolor], 29 oncelots [L. pardalis], 6 jaguarondis [P. yagouaroundi], 2 margays [L. wiedii], 14 little spotted cats [L. tigrinus], 3 pampas cats [L. pajeros] and 9 jaguars [Panthera onca]) were tested for Ehrlichia spp. infection. Using IFA 5/72 (7\%) animals tested positive for $E$. canis antibodies and $11 / 72(15.3 \%)$ animals were positive for $E$. canis by nested-PCR based on $16 \mathrm{~S}$ rRNA gene. Nested-PCR positive samples were submitted to another omp-1 gene based nested-PCR and only four samples tested positive. Sequencing of the 16S rRNA gene obtained showed $97 \%$ identity to E. canis strain Jaboticabal. However, based on omp-1 sequences, Ehrlichia sp. detected from Brazilian felids may be a novel Ehrlichia species. It was the first study of molecular detection of Ehrlichia sp. in Brazilian wild felids (ANDRÉ et al., 2010).

\section{Public Health}

There are to date two recognized diseases caused by Ehrlichia species: human monocytic ehrlichiosis (HME) caused by E. chaffeensis; and human granulocytic ehrlichiosis (HGE) due to E. ewingii (OLANO; WALKER, 2002). Other rickettsial agents, A. phagocytophilum and N. sennetsu also cause disease in humans. 
HME and HGE have been described worldwide (OTEO et al., 2000; GUILLAUME et al., 2002; GARDNER et al., 2003; RUSCIO; CINCO, 2003; MASTRANDREA et al., 2006). Three human ehrlichiosis cases have been serologically identified as HME in Brazil since 1980 (CALIC et al., 2004; COSTA et al., 2005, 2006) but molecular confirmation has not been performed. The disease in humans has been suggested serologically in other South American countries including Argentina (RIPOLL et al., 1999), Chile (LÓPEZ et al., 2003) and Peru (MORO et al., 2009). The lack of molecular characterization of the organism precludes any conclusion regarding the pathogenic agent in these cases.

An E. canis isolate has been successfully obtained in cell culture from blood of an asymptomatic person in Venezuela (PEREZ et al., 1996). The genetic sequence from this isolate was identical to $E$. canis isolates infecting dogs and $R$. sanguineus ticks in the same area of Venezuela, suggesting that human infection may be transmitted by $R$. sanguineus ticks (UNVER et al., 2001). Ehrlichia canis DNA was also amplified from blood of six human patients with clinical signs of HME in Venezuela, suggesting that E. canis can be associated with clinical manifestation in humans (PEREZ et al., 2006). In addition, the genetic characterization of the entire 16S rRNA gene of two strains of E. canis in Botucatu region, São Paulo State, Brazil, showed that one strain naturallyinfecting dogs was identical to the Venezuelan strain infecting humans (DINIZ et al. 2007). Thus, E. canis strains from Brazil may be capable of infecting humans.

Infestations by the brown dog tick, $R$. sanguineus, in humans have been reported worldwide (MANFREDI et al., 1999; GUGLIELMONE et al., 1991; FELZ et al., 1996; VENZAL et al., 2003; DEMMA et al., 2005). They were observed twice in Brazil, in the city of Goiania, Goiás State, Central-Western region where larvae, nymph and adult stages of $R$. sanguineus were found (LOULY et al. 2006), and in the city of Recife, Pernambuco State, Northeastern region, where only adult ticks were found parasitizing humans (DANTAS-TORRES et al., 2006). In the city of Londrina, Paraná State, Southern Brazil, owners of dogs with ticks were more likely to have been exposed to ticks themselves. Only $10 \%$ of the owners who occasionally interacted with their dogs while more than $25 \%$ of the owners who frequently or very frequently interacted reported past tick infestations (TRAPP et al., 2006). Thus, interaction between human beings and $R$. sanguineus is likely to be more common than is usually recognized (DANTAS-TORRES, 2008).

Ehrlichia ewingii, an agent known to cause granulocytic ehrlichiosis in dogs, was recognized in 1998 to cause infections in humans (BULLER et al., 1999), but it has not been identified as an infecting agent of humans in Brazil. A single case of ehrlichiosis caused by an Ehrlichia ruminantium-like bacterium, called the Panola Mountain Ehrlichia, has been identified in a 31-year-old man from Georgia, United States (REEVES et al., 2008).

Human exposure to tick vectors is seasonal and occurs predominantly in rural and suburban areas involving recreational, peridomestic, occupational, and military activities (DEMMA et al., 2005). Both forms of human ehrlichiosis (monocytic and granulocytic) have common clinical and laboratory manifestations that include fever, headache, myalgia and malaise, thrombocytopenia, leukopenia, and elevated liver enzymes (OLANO et al., 2003;
STONE et al., 2004). Infection by E. chaffeensis can cause a severe form of HME that can be life-threatening in HIV-infected patients (PADDOCK et al., 2001). Central nervous system infection is found rarely in HGE, whereas rashes are common in HME cases. The key for HME or HGE diagnosis is the identification of fever and thrombocytopenia, leukopenia, and elevated serum alanine-amino transferase in a patient exposed to ticks in endemic areas during times of tick activity (STONE et al., 2004; OLANO et al., 2003).

The first case of HME diagnosed in the United States was in a 51-year-old man who became ill in April 1986, 12 to 14 days after bitten by ticks in rural Arkansas (MAEDA et al., 1987). The disease was first thought to be caused by the canine pathogen E. canis. However, E. chaffeensis was shown to be the main causative agent of HME in the US in the 1990's (BAKKEN et al., 1994).

The first study using IFA was carried out in 1998 for E. chaffeensis infection in Minas Gerais State, Southeastern Brazil, in which no reactivity was found in 473 students from four schools (GALVÂO et al., 2002). The two first suspected cases of human ehrlichiosis in Brazil occurred in 2001, in Minas Gerais State, Southeastern Brazil (CALIC et al., 2004). The first patient was a 39-year-old man suspected of harboring the Brazilian Spotted Fever (BSF) agent. He had fever, headache, nausea, vomiting, myalgia, conjunctivitis, respiratory and renal failure. IFA testing for BSF and murine typhus, microagglutination testing for leptospirosis, and ELISA testing for yellow fever and dengue were performed and they were all negative. However, IFA detected antibodies against $E$. chaffeensis. Antibodies against $A$. phagocytophilum were not present. The second patient was a 20 -year-old man presenting similar clinical signs. Antibodies were detected against E. chaffeensis, but not against $A$. phagocytophilum. Based on clinical and serologic results a suggestive diagnosis of HME was established.

Nine of 771 (1.2\%) febrile patients had antibodies against E. chaffeensis by IFA in a study conducted in Minas Gerais, Southeastern Brazil, from 2001 to 2005. This case series resulted from a specific protocol to search for rickettsial agents as a cause of fever (COSTA et al., 2006). In the study, all patients reported tick bite prior to the disease. Based on the accepted criteria for diagnosis (WALKER, 2000), all cases had epidemiological and serologic findings consistent with HME (COSTA et al., 2006).

In 2001, another IFA serosurvey for rickettsial agents conducted in healthy individuals from a rural community in Minas Gerais State showed that $46 / 437(10.5 \%)$ had antibodies against $E$. chaffeensis (COSTA et al., 2005). The infection rate was higher among people living in farms when compared to those living in the village. History of tick exposure was widespread affecting roughly $100 \%$ of this population.

IFA is considered the gold standard for clinical diagnosis of HME. However, it is important to note the cross-reactivity between $E$. canis and E. chaffeensis. There is only one description of $E$. chaffeensis (from a deer) confirmed by sequencing in Brazil, however E. canis in dogs is common and widespread. The authors' hypothesis is that some, if not all, human cases attributed to E. chaffeensis in Brazil are actually caused by E. canis (DINIZ et al., 2007).

The first molecular surveillance for tick-borne diseases on humans was recently conducted in rural areas of Rondônia and São Paulo States, Northern and Southeastern Brazil, respectively 
(LABRUNA et al., 2007). No Ehrlichia DNA was detected by real-time PCR in 75 blood samples from febrile patients with history of tick exposure.

In summary, suspected human ehrlichiosis has been serologically suggested in Brazil since 2001. The surveillance studies are limited and restricted to only a few geographic areas. Comprehensive epidemiological studies using both serological and molecular methods are needed to fully establish the extent and importance of human ehrlichiosis in Brazil.

\section{Conclusion}

In conclusion, two Ehrlichia species, E. canis and E. chaffeensis, have been confirmed to occur in Brazil to date. Only E. canis has been successfully isolated in cell cultures from clinical samples of dogs. The disease caused by $E$. canis is considered endemic in dogs from several regions of Brazil, whereas the infection by E. chafeensis has been found in a wild reservoir. Although human ehrlichiosis has been serologically suggested in Brazil, the extent of the disease and its causative agent remain unknown.

\section{Acknowledgements}

We thank Profa. Dra. Rosangela Zacarias Machado (Faculdade de Ciências Agrárias e Veterinárias - UNESP, Jaboticabal, São Paulo) for her corrections and suggestions made to the manuscript.

\section{References}

AGUIAR, D. M. et al. Diagnóstico sorológico de erliquiose canina com antígeno brasileiro de Ehrlichia canis. Ciência Rural, v. 37, n. 3 , p. 796-802, 2007a.

AGUIAR, D. M. et al. Prevalence of Ehrlichia canis (Rickettsiales: Anaplasmataceae) in dogs and Rhipicephalus sanguineus (Acari: Ixodidae) ticks from Brazil. Journal of Medical Entomology, v. 44, n. 1, p. 126-132, 2007b.

AGUIAR, D. M.; HAGIWARA, M. K.; LABRUNA, M. B. In vitro isolation and molecular characterization of an Ehrlichia canis strain from São Paulo, Brazil. Brazilian Journal of Microbiology, v. 39, n. 3, p. 489-493, 2008.

ALLEMAN, A. R. et al. Recombinant major antigenic protein 2 of Ehrlichia canis: a potential diagnostic tool. Journal of Clinical Microbiology, v. 39, n. 7, p. 2494-2499, 2001.

ANDEREG, P. I.; PASSOS, L. M. F. Erliquiose canina - Revisão. Clinica Veterinária, v. 4, n. 19, p. 31-38, 1999.

ANDRÉ, M. R. et al. Molecular and serologic detection of Ehrlichia spp. in endangered Brazilian wild captive felids. Journal of Wildlife Diseases, v. 46, n. 3, p. 1017-1023, 2010.

APFALTER, P.; REISCHL, U.; HAMMERSCHLAG, M. R. In-house nucleic acid amplification assays in research: how much quality control is needed before one can rely upon the results? Journal of Clinical Microbiology, v. 43, n. 12, p. 5835-5841, 2005.
BAKKEN, J. S. et al. Human granulocytic ehrlichiosis in the upper Midwest United States. A new species emerging? Journal of the American Medical Association, v. 272, n. 3, p. 212-218, 1994.

BORIN, S.; CRIVELENTI, L. Z.; FERREIRA, F. A. Aspectos epidemiológicos, clínicos e hematológicos de 251 cães portadores de mórula de Ehrlichia spp. naturalmente infectados. Arquivo Brasileiro de Medicina Veterinária e Zootecnia, v. 61, n. 3, p. 566-571, 2009.

BREITSCHWERDT, E. B et al. Molecular evidence supporting Ehrlichia canis-like infection in Cats. Journal of Veterinary Internal Medicine, v. 16, n. 6, p. 642-649, 2002.

BULLA, C. et al. The relationship between the degree of thrombocytopenia and infection with Ehrlichia canis in an endemic area. Veterinary Research, v. 35, n. 1, p. 141-146, 2004.

BULLER, R. S. et al. Ehrlichia ewingii, a newly recognized agent of human ehrlichiosis. New England Journal of Medicine, v. 341, n. 3, p. $148-155,1999$.

CADMAN, H. F.; KELLY, P. J.; MATTHEWMAN, L. A. Comparison of the dot-blot enzyme linked immunoassay with immunofluorescence for detecting antibodies to Ehrlichia canis. Veterinary Record, v. 135, n. 15, p. 362, 1994.

CALIC, S. B. et al. Human ehrlichioses in Brazil: First suspect cases. The Brazilian Journal of Infectious Diseases, v. 8, n. 3, p. 259-262, 2004.

CARLOS, R. S. A. et al. Frequencia de Anticorpos anti- Erhlichia canis, Borrelia burgdorferi e Antígenos de Dirofilaria immitis em cães na microregião Ilhéus - Itabuna, Bahia, Brazil. Revista Brasileira de Parasitologia Veterinária, v. 16, n. 3, p. 117-120, 2007.

CARVALHO, F. S. et al. Epidemiological and molecular study of Ehrlichia canis in dogs in Bahia, Brazil. Genetic and Molecular Research, v. 7, n. 3, p. 657-662, 2008.

CASTRO, M. B. et al. Experimental acute canine monocytic ehrlichiosis: clinicopathological and immunopathological findings. Veterinary Parasitology, v. 119, n. 1, p. 73-86, 2004.

COCCO, R. et al. Ehrlichiosis and rickettsiosis in a canine population of Northern Sardinia. Annals of the New York Academy of Sciences, v. 990, p. 126-130, 2003.

COSTA Jr, L. M. C. et al. Sero-prevalence and risk indicators for canine ehrlichiosis in three rural areas of Brazil. The Veterinary Journal, v. 174, n. 3, p. 673-676, 2007.

COSTA, J. O. et al. Ehrlichia canis infection in a dog in Belo HorizonteBrazil. Arquivos Escola Veterinária UFMG, v. 25, p. 199-200, 1973.

COSTA, P. S. G. et al. More about human monocytotropic ehrlichiosis in Brazil: serological evidence of nine new cases. The Brazilian Journal of Infectious Diseases, v. 10, n. 1, p. 7-10, 2006.

COSTA, P. S. G.; BRIGATTE, M. E.; GRECO, D. B. Antibodies to Rickettsia rickettsii, Rickettsia typhi, Coxiella burnetii, Bartonella henselae, Bartonella quintana, and Ehrlichia chaffeensis among healthy population in Minas Gerais, Brazil. Memórias do Instituto Oswaldo Cruz, v. 100, n. 8, p. 853-859, 2005.

DAGNONE, A. S. et al. Molecular diagnosis of Anaplasmataceae organisms in dogs with clinical and microscopical signs of ehrlichiosis. Revista Brasileira de Parasitologia Veterinária, v. 18, n. 4, p. 20-25, 2009.

DAGNONE, A. S. et al. Ehrlichiosis in anemic, thrombocytopenic, or tick-infested dogs from a hospital population in South Brazil. Veterinary Parasitology, v. 117, n. 4, p. 285-290, 2003. 
DAGNONE, A. S.; MORAIS, H. S. A.; VIDOTTO, O. Erliquiose nos animais e no homem. Semina Agrárias, v. 22, n. 2, p. 191-201, 2001.

DANTAS-TORRES, F. The brown dog tick, Rhipicephalus sanguineus (Latreille, 1806) (Acari: Ixodidae): From taxonomy to control. Veterinary Parasitology, v. 152, n. 3-4, p. 173-185, 2008.

DANTAS-TORRES, F; FIGUEIREDO, L. A.; BRANDÃO-FILHO, S. P. Rhipicephalus sanguineus (Acari: Ixodidae), the brown dog tick, parasitizing humans in Brazil. Revista da Sociedade Brasileira de Medicina Tropical, v. 39, n. 1, p. 64-67, 2006.

DEMMA, L. J. et al. Epidemiology of human ehrlichiosis and anaplasmosis in the United States, 2001-2002. American Journal of Tropical Medicine and Hygiene, v. 73, n. 2, p. 400-409, 2005.

DINIZ, P. P. V. P. et al. Serum cardiac troponin I concentration in dogs with ehrlichiosis. Journal of Veterinary Internal Medicine, v. 22, n. 5 , p. 1136-1143, 2008.

DINIZ, P. P. V. P. et al. Surveillance for zoonotic vector-borne infections using sick dogs from Southeastern Brazil. Vector-Borne and Zoonotic Diseases, v. 7, n. 4, p. 689-697, 2007.

DUMLER, J. S. et al. Ehrlichioses in humans: epidemiology, clinical presentation, diagnosis, and treatment. Clinical Infectious Diseases, v. 45, Supl. 1, p. 45-51, 2007.

DUMLER, J. S. et al. Reorganization of genera in the families Rickettsiaceae and Anaplasmataceae in the order Rickettsiales: unification of some species of Ehrlichia with Anaplasma, Cowdria with Ehrlichia and Ehrlichia with Neorickettsia, descriptions of six new species combinations and designation of Ehrlichia equi and 'HGE agent' as subjective synonyms of Ehrlichia phagocytophila. Internation Journal of Systematic and Evolutionary Microbiology, v. 51, n. 6, p. 2145-2165, 2001.

FABURAY, B. et al. Point seroprevalence survey of Ehrlichia ruminantium infection in small ruminants in The Gambia. Clinical and Diagnostic Laboratory Immunology, v. 12, n. 4, p. 508-512, 2005.

FARIA, J. L. M. et al. Ehrlichia canis morulae and DNA detection in whole blood and spleen aspiration samples. Revista Brasileira de Parasitologia Veterinária, v. 19, n. 2, p. 98-102, 2010.

FELZ, M. W.; DURDEN, L. A.; OLIVER Jr, J. H. Ticks parasitizing humans in Georgia and South Carolina. Journal of Parasitology, v. 82, n. 3, p. 505-508, 1996.

FILONI, C. et al. First evidence of Feline Herpesvirus, Calicivirus, Parvovirus, and Ehrlichia Exposure in Brazilian Free-ranging Felids. Journal of Wildlife Diseases, v. 42, n. 2, p. 470-477, 2006.

FRANK, J. R.; BREITSCHWERDT, E. B. A retrospective study of ehrlichiosis in 62 dogs from North Carolina and Virginia. Journal of Veterinary Internal Medicine, v. 13, n. 3, p. 194-201, 1999.

GALVÃO, M. A. M. et al. Rickettsioses emergentes e reemergentes numa região endêmica do estado de Minas Gerais, Brasil. Cadernos de Saúde Pública, v. 18, n. 6, p. 1593-1597, 2002.

GARDNER, S. L. et al. National surveillance for the human ehrlichioses in the United States, 1997-2001, and proposed methods for evaluation of data quality. Annals of the New York Academy of Sciences, v. 990, p. 80-89, 2003.

GUGLIELMONE, A. A.; MANGOLD, A. J.; VIÑABAL, A. E. Ticks (Ixodidae) parasitizing humans in four provinces of north-western Argentina. Annals of Tropical Medicine and Parasitology, v. 85, n. 5, p. $539-542,1991$.
GUILLAUME, B. et al. Seroprevalence of human granulocytic ehrlichiosis infection in Belgium. European Journal of Clinical Microbiology \& Infectious Diseases, v. 21, n. 5, p. 397-400, 2002.

HARRUS, S. et al. Amplification of ehrlichial DNA from dogs 34 months after infection with Ehrlichia canis. Journal of Clinical Microbiology, v. 36, n. 1, p. 73-76, 1998.

HARRUS, S. et al. Comparison of simultaneous splenic sample PCR with blood sample PCR for diagnosis and treatment of experimental Ehrlichia canis infection. Antimicrobial Agents and Chemotherapy, v. 48, n. 11, p. 4488-4490, 2004.

HARRUS, S. et al. Comparison of three enzyme-linked immunosorbant assays with the indirect immunofluorescent antibody test for the diagnosis of canine infection with Ehrlichia canis. Veterinary Microbiology, v. 86, n. 4, p. 361-368, 2002.

HILDEBRANDT, P. K. et al. Ultrastructure of Ehrlichia canis. Infection and Immunity, v. 7, n. 2, p. 265-271, 1973.

HOSKINS, J. D. Ehrlichial diseases of dogs: diagnosis and treatment. Canine Practice, v. 16, n. 3, p. 13-21, 1991.

HUXSOLL, D. L. et al. Tropical canine pancytopenia. Journal of American Veterinary Medicine Association, v. 157, n. 11, p. 1627-1632, 1970.

INOKUMA, H. et al. Prevalence of tick-borne Rickettsia and Ehrlichia in Ixodes persulcatus and Ixodes ovatus in Tokachi district, Eastern Hokkaido, Japan. Journal of Veterinary Medical Science, v. 69, n. 6, p. 661-664, 2007.

INOKUMA, H.; OHNO, K.; YAMAMOTO, S. Serosurvey of Ehrlichia canis and Hepatozoon canis infection in dogs in Yamaguchi Prefecture, Japan. Journal of Veterinary Medical Science, v. 61, n. 10, p. $1153-1155,1999$.

IQBAL, Z.; CHAICHANASIRIWITHAYA, W.; RIKIHISA, Y. Comparison of PCR with other tests for early diagnosis of canine ehrlichiosis. Journal of Clinical Microbiology, v. 32, n. 7, p. 1658-1662, 1994.

KAWAHARA, M. et al. Ehrlichia chaffeensis in Sick Deer, Nara Park, Japan. Emerging Infectious Diseases, v. 15, n. 12, p. 1991-1993, 2009.

KEEFE, T. J.; SALYER, P. E.; RISTIE, M. Distribution of Ehrlichia canis among military working dogs in the world and selected civilian dogs United States. Journal of American Veterinary Association, v. 181, n. 3, p. 236-238, 1982.

LABARTHE, N. et al. Serologic prevalence of Dirofilaria immitis, Ehrlichia canis, and Borrelia burgdorferi infections in Brazil. Veterinary Therapeutics, v. 4, n. 1, p. 67-75, 2003.

LABRUNA, M. B. et al. A preliminary investigation of Ehrlichia species in ticks, humans, dogs, and capybaras from Brazil. Veterinary Parasitology, v. 143, n. 2, p. 189-195, 2007.

LABRUNA, M. B.; PEREIRA, M. C. Carrapato em cães no Brasil. Clínica Veterinária, v. 6, n. 30, p. 24-32, 2001.

LEE, M. et al. Natural co-infection of Ehrlichia chaffeensis and Anaplasma bovis in a deer in South Korea. The Journal of Veterinary Medical Science, v. 71, n. 1, p. 101-103, 2009.

LÓPEZ, J. et al. Ehrlichiosis humana en Chile, evidencia serológica. Revista Médica de Chile, v. 131, n. 1, p. 67-70, 2003. 
LÓPEZ, L. et al. Development of a sensitive and specific indirect enzymelinked immunosorbent assay based on a baculovirus recombinant antigen for detection of specific antibodies against Ehrlichia canis. Journal of Veterinary Diagnostic Investigation, v. 19, n. 6, p. 635-642, 2007.

LOULY, C. C. B. et al. Ocorrência de Rhipicephalus sanguineus em trabalhadores de clínicas veterinárias e canis, no Município de Goiânia, GO. Ciência Animal Brasileira, v. 7, n. 1, p. 103-106, 2006.

MAANEN, C. et al. An interlaboratory comparison of immunohistochemistry and PCR methods for detection of Neospora caninum in bovine foetal tissues. Veterinary Parasitology, v. 126, n. 4, p. 351-364, 2004.

MACHADO, R. Z. et al. Detection of Ehrlichia chaffeensis in Brazilian marsh deer (Blastocerus dichotomus). Veterinary Parasitology, v. 139, n. 1-3, p. 262-266, 2006.

MACIEIRA, D. B. et al. Prevalence of Ehrlichia canis infection in thrombocytopenic dogs from Rio de Janeiro, Brazil. Veterinary Clinical Pathology, v. 34, n. 1, p. 44-48, 2005.

MAEDA, K. et al. Human infection with Ehrlichia canis, a leukocytic rickettsia. New England Journal of Medicine. v. 316, n. 14, p. 853-856, 1987.

MANFREDI, M. T. et al. Tick species parasitizing people in an area endemic for tick-borne diseases in north-western Italy. Parassitologia, v. 41, n. 4, p. 555-560, 1999.

MASTRANDREA, S. et al. Two cases of human granulocytic ehrlichiosis in Sardinia, Italy confirmed by PCR. Annals of the New York Academy of Sciences, v. 1078, p. 548-551, 2006.

MATTHEWMAN, L.; KELLY, P. J.; WRAY, K. Antibodies in cat sera from southern Africa react with antigens of Ehrlichia canis. Veterinary Record, v. 138, n. 15, p. 364-365, 1996.

MOREIRA, S. M. et al. Retrospective study (1998-2001) on canine ehrlichiosis in Belo Horizonte, MG, Brazil. Arquivo Brasileiro de Medicina Veterinária e Zootecnia, v. 55, n. 2, p. 141-147, 2003.

MOREIRA, S. M.; MACHADO, R. Z.; PASSOS, L. F. Detection of Ehrlichia canis in bone marrow aspirates of experimentally infected dogs. Ciência Rural, v. 35, n. 4, p. 958-960, 2005.

MORO, P. L. et al. Short Report: Serologic evidence of human ehrlichiosis in Peru. The American Journal of Tropical Medicine and Hygiene, v. 80, n. 2, p. 242-244, 2009.

MUNDIM, A. V. et al. Clinical and hematological signs associated with dogs naturally infected by Hepatozoon sp. and with other hematozoa: A retrospective study in Uberlândia, Minas Gerais, Brazil. Veterinary Parasitology, v. 153, n. 1-2, p. 3-8, 2008.

MYLONAKIS, M. E. et al. Evaluation of cytology in the diagnosis of acute canine monocytic ehrlichiosis (Ehrlichia canis): a comparison between five methods. Veterinary Microbiology, v. 91, n. 2-3, p. 197-204, 2003.

NAKAGHI, A. C. H. et al. Sensitivity evaluation of a single-step PCR assay using Ehrlichia canis $p 28$ gene as a target and its application in diagnosis of canine ehrlichiosis. Revista Brasileira de Parasitologia Veterinária, v. 19, n. 2, p. 75-79, 2010.

NAKAGHI, A. C. H. et al. Canine ehrlichiosis: clinical, hematological, serological and molecular aspects. Ciência Rural, v. 38, n. 3, p. 766-770, 2008.
NDIP, L. M. et al. Molecular and clinical evidence of Ehrlichia chaffeensis infection in Cameroonian patients with undifferentiated febrile illness. Annals of Tropical Medicine and Parasitology, v. 103, n. 8, p. 719-725, 2009.

NEER, T. M. Canine monocytic granulocytic ehrlichiosis. In: GREENE, C. E. (Ed). Infectious Disease of the Dog and Cat. $2^{\text {nd }}$ ed. Philadelphia: W. B. Saunders, 1998. p. 139-147.

O'DWYER, L. H. et al. Prevalence, hematology and serum biochemistry in stray dogs naturally infected by Hepatozoon canis in São Paulo. Arquivo Brasileiro de Medicina Veterinária e Zootecnia, v. 58, n. 4, p. 688-690, 2006.

OHASHI, N. et al. Cloning and characterization of multigenes encoding the immunodominant 30-kilodalton major outer membrane proteins of Ehrlichia canis and application of the recombinant protein for serodiagnosis. Journal of Clinical Microbiology, v. 36, n. 9, p. 2671 2680, 1998.

OLANO, J. P. et al. Human monocytotropic ehrlichiosis, Missouri. Emerging Infectious Diseases, v. 9, n. 12, p. 1579-1586, 2003.

OLANO, J. P.; WALKER, D. H. Human ehrlichioses. The Medical Clinics of North America, v. 86, n. 2, p. 375-392, 2002.

OLIVEIRA, D. et al. Anti- Ehrlichia canis antibodies detection by "DotELISA" in naturally infected dogs. Revista Brasileira de Parasitologia Veterinária, v. 9, n. 1, p. 1-5, 2000.

OLIVEIRA, L. P. et al. Molecular analysis of the rRNA genes of Babesia spp and Ehrlichia canis detected in dogs from Ribeirão Preto, Brazil. Brazilian Journal of Microbiology, v. 40, n. 2, p. 238-240, 2009a.

OLIVEIRA, L. S. et al. Molecular detection of Ehrlichia canis in cats in Brazil. Clinical Microbiology and Infection, v. 15, Supl. 2, p. 53-54, 2009b.

OLIVEIRA, L. S. et al. First report of Ehrlichia ewingii detected by molecular investigation in dogs from Brazil. Clinical Microbiology and Infection, v. 15, Supl. 2, p. 55-56, 2009c.

ORIÁ, A. P. et al. Ophthalmic, hematologic and serologic findings in dogs with suspected Ehrlichia canis infections. Revista Brasileira de Ciência Veterinaria, v. 15, n. 2, p. 94-97, 2008.

ORTUÑO, A. et al. Serological evidence of Ehrlichia spp. exposure in cats from Northeastern Spain. Journal of Veterinary Medicine B. Infectious Diseases and Public Health, v. 52, n. 5, p. 246-248, 2005.

OTEO, J. A. et al. First report of human granulocytic ehrlichiosis from southern Europe (Spain). Emerging Infectious Diseases, v. 6, n. 4, p. 430-432, 2000.

PADDOCK, C. D. et al. Infections with Ehrlichia chaffeensis and Ehrlichia ewingii in persons coinfected with human immunodeficiency virus. Clinical Infectious Diseases. v. 33, n. 9, p. 1586-1594, 2001.

PADDOCK, C. D.; CHILDS, J. E. Ehrlichia chaffeensis: a prototypical emerging pathogen. Clinical Microbiology Reviews, v. 16, n. 1, p. 37-64, 2003.

PEAVY, G. M.; HOLLAND, C. J.; DUTTA, S. K. Suspected ehrlichial infection in five cats from a household. Journal of the American Veterinary Medical Association, v. 210, n. 2, p. 231-234, 1997.

PEIXOTO, C. C. et al. Quantification of Ehrlichia ruminantium by real time PCR. Veterinary Microbiology, v. 107, n. 3-4, p. 273-278, 2005. 
PEREZ, M. et al. Human Infection with Ehrlichia canis accompanied by clinical signs in Venezuela. Annals of the New York Academy of Sciences, v. 1078, p. 110-117, 2006.

PEREZ, M.; RIKIHISA, Y.; WEN, B. Ehrlichia canis-like agent isolated from a man in Venezuela: antigenic and genetic characterization. Journal of Clinical Microbiology, v. 34, n. 9, p. 2133-2139, 1996.

PETER, T. F.; BURRIDGE, M. J.; MAHAN, S. M. Ehrlichia ruminantium infection (heartwater) in wild animals. Trends in Parasitology, v. 18, n. 5, p. 214-218, 2002.

REEVES, W. K. et al. The first report of human illness associated with the Panola Mountain Ehrlichia species: A case report. Journal of Medical Case Reports, v. 2, p. 139, 2008.

RIPOLL, C. M. et al. Evidence of rickettsial spotted fever and ehrlichial infections in a subtropical territory of Jujuy, Argentina. The American Journal of Tropical Medicine and Hygiene, v. 61, n. 2, p. 350-354, 1999.

RISTIC, M. et al. Evidence of a serologic relationship between Ehrlichia canis and Rickettsia sennetsu. The American Journal of Tropical Medicine and Hygiene, v. 30, n. 6, p. 1324-1328, 1981.

RISTIC, M. et al. Serological diagnosis of tropical canine pancytopenia by indirect immunofluorescence. Infection and Immunity, v. 6, n. 3, p. 226-231, 1972.

RUSCIO, M.; CINCO, M. Human granulocytic ehrlichiosis in Italy: first report on two confirmed cases. Annals of the New York Academy of Sciences, v. 990, p. 350-352, 2003.

SAINZ, A. et al. Seroprevalence of canine Ehrlichiosis in Castilla-León (North West Spain). Preventive Veterinary Medicine, v. 29, n. 1, p. 1-7, 1996.

SAITO, T. B. et al. Canine Infection by Rickettsiae and Ehrlichiae in Southern Brazil. American Journal of Tropical Medicine and Hygiene, v. 70, n. 1, p. 102-108, 2008.

SANTOS, F. et al. Molecular evaluation of the incidence of Ehrlichia canis, Anaplasma platys and Babesia spp. in dogs from Ribeirão Preto, Brazil. The Veterinary Journal, v. 179, n. 1, p. 145-148, 2009.

SILVA, J. N. et al. Soroprevalência de anticorpos anti-Ehrlichia canis em cães de Cuiabá, Mato Grosso. Revista Brasileira de Parasitologia Veterinária, v. 19, n. 2, p. 108-111, 2010.

SOARES, A. O. et al. Avaliação ectoparasitológica e hemoparasitológica em cães criados em apartamentos e casas com quintal na cidade de Juiz de Fora, MG. Revista Brasileira de Parasitologia Veterinária, v. 15, n. 1, p. 13-16, 2006.

SOLANO-GALLEGO, L. et al. Serological and molecular evidence of exposure to arthropod-borne organisms in cats from northeastern Spain. Veterinary Microbiology, v. 118, n. 3-4, p. 274-277, 2006.

SOUZA, B. M. P. S. et al. Prevalence of ehrlichial infection among dogs and ticks in Northeastern Brazil. Revista Brasileira de Parasitologia Veterinária, v. 19, n. 2, p. 89-93, 2010.

STONE, J. H. et al. Human monocytic ehrlichiosis. Journal of the American Medical Association, v. 292, n. 18, p. 2263-2270, 2004.

SUKSAWAT, J. et al. Coinfection with three Ehrlichia species in dogs from Thailand and Venezuela with emphasis on consideration of $16 S$ ribosomal DNA secondary structure. Journal of Clinical Microbiology, v. 39, n. 1, p. 90-93, 2001.
TAMAMOTO, C. et al. Detection of Ehrlichia muris DNA from sika deer (Cervus nippon yesoensis) in Hokkaido, Japan. Veterinary Parasitology, v. 150, n. 4, p. 370-373, 2007.

TORRES, H. M. et al. Isolamento e propagação da Ehrlichia canis em células DH82 e obtenção de antígeno para reação de imunofluorescência indireta. Revista Brasileira de Ciência Veterinária, v. 9, n. 2, p. 77-82, 2002.

TRAPP, S. M. et al. Seroepidemiology of canine babesiosis and ehrlichiosis in a hospital population. Veterinary Parasitology, v. 140, n. 3-4, p. 223-230, 2006.

UENO, T. E. H. et al. Ehrlichia canis em cães atendidos em hospital veterinário de Botucatu, Estado de São Paulo, Brasil. Revista Brasileira de Parasitologia Veterinária, v. 18, n. 3, p. 57-61, 2009.

UNVER, A. et al. Molecular and antigenic comparison of Ehrlichia canis isolates from dogs, ticks, and a human in Venezuela. Journal of Clinical Microbiology, v. 39, n. 8, p. 2788-2793, 2001.

VENZAL, J. M. et al. Ticks (Ixodida: Ixodidae) parasitising humans in Uruguay. Annals of Tropical Medicine and Parasitology, v. 97, n. 7, p. 769-772, 2003.

WALKER, D. H.; THE TASK FORCE ON CONSENSUS APPROACH FOR EHRLICHIOSIS. Diagnosing human ehrlichioses: current status and recommendations. American Society for Microbiology News, v. 66, n. 5 , p. $287-290,2000$.

WALKER, J. S. et al. Clinical and Clinicopathologic findings in tropical canine pancytopenia. Journal of American Veterinary Medicine Association, v. 157, n. 1, p. 43-55, 1970.

WANER, T. et al. Significance of serological testing for ehrlichial diseases in dogs with special emphasis on the diagnosis of canine monocytic ehrlichiosis caused by Ehrlichia canis. Veterinary Parasitology, v. 95, n. 1, p. 1-15, 2001.

WANER, T.; STRENGER, C.; KESARY, A. Comparison of a clinicbased ELISA test kit with the immunofluorescence test for the assay of Ehrlichia canis antibodies in dogs. Journal of Veterinary Diagnostic Investigation, v. 12, n. 3, p. 240-244, 2000.

XAVIER, M. S. et al. Avaliação da coagulação plasmática e plaquetometria em cães não infectados e infectados experimentalmente com Ehrlichia spp. Arquivo Brasileiro de Medicina Veterinária e Zootecnia, v. 61, n. 5, p. 1049-1053, 2009.

YABSLEY, M. J. Natural history of Ehrlichia chaffeensis: vertebrate hosts and tick vectors from the United States and evidence for endemic transmission in other countries, Veterinary Parasitology, v. 167, n. 2-4, p. $136-148,2010$.

YABSLEY, M. J. et al. Ehrlichia ewingii infection in white-tailed deer (Odocoileus virginianus). Emerging Infectious Diseases, v. 8, n. 7, p. 668-671, 2002.

YABSLEY, M. J.; LOFTIS, A. D.; LITTLE, S. E. Natural and experimental infection of white-tailed deer (Odocoileus virginianus) from the United States with an Ehrlichia sp. closely related to Ehrlichia ruminantium. Journal of Wildlife Diseases, v. 44, n. 2, p. 381-387, 2008.

ZHANG, X et al. Identification of 19 polymorphic major outer membrane protein genes and their immunogenic peptides in Ehrlichia ewingii for use in a serodiagnostic assay. Clinical and Vaccine Immunology, v. 15, n. 3, p. 402-411, 2008. 